Pacific Journal of Mathematics

MEAN VALUE ITERATION OF NONEXPANSIVE MAPPINGS IN 


\title{
MEAN VALUE ITERATION OF NONEXPANSIVE MAPPINGS IN A BANACH SPACE
}

\author{
Curtis L. Outlaw
}

This paper applies a certain method of iteration, of the mean value type introduced by $W$. R. Mann, to obtain two theorems on the approximation of a fixed point of a mapping of a Banach space into itself which is nonexpansive (i.e., a mapping which satisfies $\|T x-T y\| \leqq\|x-y\|$ for each $x$ and $y)$.

The first theorem obtains convergence of the iterates to a fixed point of a nonexpansive mapping which maps a compact convex subset of a rotund Banach space into itself.

The second theorem obtains convergence to a fixed point provided that the Banach space is uniformly convex and the iterating transformation is nonexpansive, maps a closed bounded convex subset of the space into itself, and satisfies a certain restriction on the distance between any point and its image.

We note that a rotation $T$ about zero of the closed unit disc in the complex plane satisfies the conditions of Theorems 1 and 2 , but the usual sequence $\left\{T^{n} x\right\}$ of iterates of $x$ does not converge unless $x$ is zero.

Definitions. If $Y$ is a Banach space, $T$ is a mapping from $Y$ into itself, and $x \in Y$, then $M(x, T)$ is the sequence $\left\{v_{n}\right\}$ defined by $v_{1}=x$ and $v_{n+1}=(1 / 2)\left(v_{n}+T v_{n}\right)$.

Following Wilansky [3, pp. 107-111], we say that a Banach space $Y$ is rotund provided that if $w \in Y, y \in Y, w \neq y$, and $\|w\|=\|y\| \leqq 1$, then $(1 / 2)\|w+y\|<1$.

THEOREM 1. Let $Y$ be a rotund Banach space, $E$ be a compact convex subset of $Y$, and $T$ be a nonexpansive mapping which maps $E$ into itself. If $x \in E$ then $M(x, T)$ converges to a fixed point of $T$.

Proof. If, for some $\mathrm{n}, v_{n}=T v_{n}$, then clearly $M(x, T)$ converges to $v_{n}$.

Hence suppose that $v_{n} \neq T v_{n}$, for each $n$. Let $z$ be a fixed point of $T$. Then $\left\{\left\|v_{n}-z\right\|\right\}$ is decreasing, for since $Y$ is rotund and

$$
\left\|T v_{n}-z\right\|=\left\|T v_{n}-T z\right\| \leqq\left\|v_{n}-z\right\|,
$$

we have that

$$
\left\|v_{n+1}-z\right\|=\left\|\frac{1}{2}\left(v_{n}+T v_{n}\right)-z\right\|<\left\|v_{n}-z\right\|
$$


Suppose that $\lim _{n}\left\|v_{n}-z\right\|=b>0$. Let $y$ be a cluster value of $\left\{v_{n}\right\}$. Then clearly $b=\|y-z\|$.

Suppose first that $y=T y$. Then for each $n$,

$$
\left\|T v_{n}-y\right\|=\left\|T v_{n}-T y\right\| \leqq\left\|v_{n}-y\right\| \text {. }
$$

Since we have assumed that $v_{n} \neq T v_{n}$ for each $n$, we have by the rotundity of $Y$ that

$$
\left\|v_{n+1}-y\right\|=\left\|\frac{1}{2}\left(v_{n}+T v_{n}\right)-y\right\|<\left\|v_{n}-y\right\| .
$$

Thus $\left\{\left\|v_{n}-y\right\|\right\}$ is decreasing, and since $y$ is a cluster value of $\left\{v_{n}\right\}$, $M(x, T)$ converges to $y$.

Now suppose that $y \neq T y$. Let $d$ denote $b-\|(1 / 2)(y+T y)-z\|$. Then $d>0$, since $Y$ is rotund, for

$$
\|T y-z\|=\|T y-T z\| \leqq\|y-z\|=b .
$$

Let $n$ be such that $\left\|y-v_{n}\right\|<d$. Then since $T$ is nonexpansive,

$$
\begin{aligned}
& \left\|\frac{1}{2}(y+T y)-v_{n+1}\right\|=\left\|\frac{1}{2}(y+T y)-\frac{1}{2}\left(v_{n}+T v_{n}\right)\right\| \\
& \quad \leqq \frac{1}{2}\left\|y-v_{n}\right\|+\frac{1}{2}\left\|T y-T v_{n}\right\| \\
& \quad \leqq\left\|y-v_{n}\right\|<d .
\end{aligned}
$$

Hence

$$
\begin{aligned}
& \left\|v_{n+1}-z\right\| \leqq\left\|v_{n+1}-\frac{1}{2}(y+T y)\right\|+\left\|\frac{1}{2}(y+T y)-z\right\| \\
& <d+(b-d)=b,
\end{aligned}
$$

a contradiction. Therefore $b=\lim _{n}\left\|v_{n}-z\right\|=0$, so that $M(x, T)$ converges to $z$.

F. E. Browder [1] has shown that each nonexpansive mapping which maps a closed bounded convex subset $E$ of a uniformly convex Bananch space into itself has a fixed point in $E$.

If such a mapping satisfies one additional requirement, we may approximate one of its fixed points using $M(x, T)$ :

THeorem 2. Let $Y$ be a uniformly convex Banach space, $E$ be a closed bounded convex subset of $Y$, and let $T$ be a nonexpansive mapping which maps $E$ into itself. Let $F$ denote the set of fixed point of $T$ in $E$, and suppose that there is a number $c$ in $(0,1)$ such that if $x \in E$, then 


$$
\|x-T x\| \geqq c d(x, F),
$$

where $d(x, F)$ denotes $\sup _{z \in F}\|x-z\|$.

If $x \in E$ then $M(x, T)$ converges to a fixed point of $T$.

Proof. The theorem is trivial if $x \in F$. Suppose that $x \in E-F$ and that $M(x, T)$ does not converge to a member of $F$. Then $v_{n} \notin F$ for each $n$. Since $Y$ is uniformly convex, we have as in the proof of Theorem 1 that if $z \in F$ then $\left\{\left\|v_{n}-z\right\|\right\}$ is decreasing.

Suppose that $b=\lim _{n} d\left(v_{n}, F\right)>0$. Since $Y$ is uniformly convex, there is an $r$ in $(0,2 b)$ such that, for $w, y$, and $z$ in $Y$, the relations

$$
\|w-z\| \leqq\|y-z\| \leqq 2 b \text { and }\|w-y\| \geqq c b
$$

imply that

$$
\left\|\frac{1}{2}(w+y)-z\right\| \leqq\|y-z\|-r .
$$

There is a positive integer $n$ and a member $z$ of $F$ such that

$$
\left\|v_{n}-z\right\|<b+\frac{r}{2}
$$

so that since

$$
\left\|T v_{n}-z\right\|=\left\|T v_{n}-T z\right\| \leqq\left\|v_{n}-z\right\|<2 b
$$

and

$$
\left\|T v_{n}-v_{n}\right\| \geqq c d\left(v_{n}, F\right) \geqq c b,
$$

we have that

$$
\begin{aligned}
\left\|v_{n+1}-z\right\| & =\left\|\frac{1}{2}\left(v_{n}+T v_{n}\right)-z\right\| \\
& \leqq\left\|v_{n}-z\right\|-r<b+\frac{r}{2}-r<b,
\end{aligned}
$$

an contradiction. Hence $\lim _{n} d\left(v_{n}, F\right)=0$.

We now need the following:

Lemma. If $s>0, z \in F$, and $r>0$ such that for some $n, v_{n}$ is in the open sphere $S(z, r)$ with center $z$ and radius $r$, then there exist $t$ in $(0, s), w$ in $F$, and an $m$ such that the closed sphere $\bar{S}(w, t)$ lies in $S(z, r)$, and for each $p, v_{m+p} \in S(w, t)$.

Proof. Recall that $\left\{\left\|v_{p}-z\right\|\right\}$ is decreasing and that we are supposing that $\left\{v_{p}\right\}$ does not converge to $z$. Let $a=\lim _{p}\left\|v_{p}-z\right\|$. 
Then $0<a<r$. Let $t=(1 / 3) \min \{r-a, s\}$.

Since $\lim _{p}\left\|v_{p}-z\right\|=a, \lim _{p} d\left(v_{p}, F\right)=0$, and $v_{p} \notin F$ for each $p$, there exist $w$ in $F$ and an $m$ such that $\left\|v_{m}-z\right\|<a+t$ and $\left\|v_{m}-w\right\|<t$.

Since $w \in F,\left\|v_{m+p}-w\right\|$ decreases as $p$ increases, so that $v_{m+p} \in S(w, t)$ for each $\mathrm{p}$. Also, if $y \in \bar{S}(w, t)$, then $y \in S(z, r)$, for

$$
\begin{aligned}
\|y-z\| & \leqq\|y-w\|+\left\|w-v_{m}\right\|+\left\|v_{m}-z\right\| \\
& <t+t+(a+t) \\
& \leqq 3\left(\frac{r-a}{3}\right)+a=r .
\end{aligned}
$$

The lemma guarantees the existence of a sequence $\left\{z_{i}\right\}$ in $F$, a sequence $\left\{t_{i}\right\}$ of positive numbers with limit 0 , and a subsequence $\left\{v_{n_{i}}\right\}$ of $\left\{v_{n}\right\}$ such that for each $i$ and each $p$,

$$
\bar{S}\left(z_{i+1}, t_{i+1}\right) \quad \text { lies in } S\left(z_{i}, t_{i}\right)
$$

and

$$
v_{n_{i}+p} \in S\left(z_{i}, t_{i}\right) \text {. }
$$

By the Cantor Intersection Theorem, $\bigcap_{i=1}^{\infty} S\left(z_{i}, t_{i}\right)$ contains exactly one point, say $w$. Clearly $\left\{z_{i}\right\}$ converges to $w$ and $w \in F$. Further, $\left\{\left\|v_{n}-w\right\|\right\}$ is decreasing and $\left\{v_{n_{i}}\right\}$ converges to $w$, so that $\left\{v_{n}\right\}$ converges to $w$. Thus we have contradicted our assumption that $M(x, T)$ does not converge to a member of $F$.

\section{REFERENCES}

1. F. E. Browder, Nonexpansive nonlinear operators in a Banach space, Proceedings of the National Academy of Sciences, U.S. A., 54 (1965) 1041-1044.

2. W. R. Mann, Mean value methods in iteration, Proc. Amer. Math. Soc. 4 (1953), 506-510.

3. A. Wilansky, Functional analysis, Blaisdell, New York, (1964).

Received March 12, 1968.

Louisiana State University in New Orleans

New ORLEans, Louisiana 70122 


\section{PACIFIC JOURNAL OF MATHEMATICS}

\section{EDITORS}

H. ROYDEN

Stanford University

Stanford, California

\section{RichaRd PIERCE}

University of Washington Seattle, Washington 98105
J. DugundJI

Department of Mathematics

University of Southern California

Los Angeles, California 90007

BASIL GORDON

University of California

Los Angeles, California 90024

\section{ASSOCIATE EDITORS}
E. F. BECKENBACH
B. H. NeUMANN
F. WOLF
K. YOSHIDA

\section{SUPPORTING INSTITUTIONS}

UNIVERSITY OF BRITISH COLUMBIA CALIFORNIA INSTITUTE OF TECHNOLOGY

UNIVERSITY OF CALIFORNIA

MONTANA STATE UNIVERSITY

UNIVERSITY OF NEVADA

NEW MEXICO STATE UNIVERSITY

OREGON STATE UNIVERSITY

UNIVERSITY OF OREGON

OSAKA UNIVERSITY

UNIVERSITY OF SOUTHERN CALIFORNIA

\author{
STANFORD UNIVERSITY \\ UNIVERSITY OF TOKYO \\ UNIVERSITY OF UTAH \\ WASHINGTON STATE UNIVERSITY \\ UNIVERSITY OF WASHINGTON \\ AMERICAN MATHEMATICAL SOCIETY \\ CHEVRON RESEARCH CORPORATION \\ TRW SYSTEMS \\ NAVAL WEAPONS CENTER
}

The Supporting Institutions listed above contribute to the cost of publication of this Journal, but they are not owners or publishers and have no responsibility for its content or policies.

Mathematical papers intended for publication in the Pacific Journal of Mathematics should be in typed form or offset-reproduced, double spaced with large margins. Underline Greek letters in red, German in green, and script in blue. The first paragraph or two must be capable of being used separately as a synopsis of the entire paper. It should not contain references to the bibliography. Manuscripts, in duplicate if possible, may be sent to any one of the four editors. Please classify according to the scheme of Math. Rev. 36, 1539-1546. All other communications to the editors should be addressed to the managing editor, Richard Arens, University of California, Los Angeles, California, 90024.

50 reprints are provided free for each article; additional copies may be obtained at cost in multiples of 50 .

The Pacific Journal of Mathematics is published monthly. Effective with Volume 16 the price per volume (3 numbers) is $\$ 8.00$; single issues, $\$ 3.00$. Special price for current issues to individual faculty members of supporting institutions and to individual members of the American Mathematical Society: $\$ 4.00$ per volume; single issues $\$ 1.50$. Back numbers are available.

Subscriptions, orders for back numbers, and changes of address should be sent to Pacific Journal of Mathematics, 103 Highland Boulevard, Berkeley, California, 94708.

PUBLISHED BY PACIFIC JOURNAL OF MATHEMATICS, A NON-PROFIT CORPORATION

Printed at Kokusai Bunken Insatsusha (International Academic Printing Co., Ltd.), 7-17. Fujimi 2-chome, Chiyoda-ku, Tokyo, Japan. 


\section{Pacific Journal of Mathematics}

\section{Vol. 30, No. $3 \quad$ November, 1969}

Willard Ellis Baxter, Topological rings with property $(Y) \ldots \ldots \ldots \ldots . \ldots 5$

Sterling K. Berberian, Note on some spectral inequalities of $C . R$.

Putnam ..................................... 573

David Theodore Brown, Galois theory for Banach algebras . ........... 577

Dennis K. Burke and R. A. Stoltenberg, A note on p-spaces and Moore spaces ........................................ 601

Rafael Van Severen Chacon and Stephen Allan McGrath, Estimates of positive contractions....................................... 609

Rene Felix Dennemeyer, Conjugate surfaces for multiple integral problems in the calculus of variations ........................... 621

Edwin O. Elliott, Measures on countable product spaces.............. 639

John Moss Grover, Covering groups of groups of Lie type .............. 645

Charles Lemuel Hagopian, Concerning semi-local-connectedness and cutting in nonlocally connected continua .................. 657

Velmer B. Headley, A monotonicity principle for eigenvalues ........... 663

John Joseph Hutchinson, Intrinsic extensions of rings . . . . . . . . . . . . . 669

Harold H. Johnson, Determination of hyperbolicity by partial

prolongations .................................. 679

Tilla Weinstein, Holomorphic quadratic differentials on surfaces in $E^{3} \ldots 697$

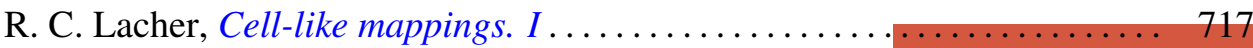

Roger McCann, A classification of centers

Curtis L. Outlaw, Mean value iteration of nonexpansive mappings in a

Banach space...

Allan C. Peterson, Distribution of zeros of solutions of a fourth order

differential equation.

Bhalchandra B. Phadke, Polyhedron inequality and strict convexity .. 765 Jack Wyndall Rogers Jr., On universal tree-like continua .

Edgar Andrews Rutter, Two characterizations of quasi-Frobenius rings

G. Sankaranarayanan and C. Suyambulingom, Some renewal theorems concerning a sequence of correlated random variables...

Joel E. Schneider, A note on the theory of primes........ . .

Richard Peter Stanley, Zero square rings .................

Edward D. Tymchatyn, The 2-cell as a partially ordered space

Craig A. Wood, On general Z.P.I.-rings................ 